\title{
Genetics of leprosy reactions: an overview
}

\author{
Vinicius Fava ${ }^{1,2,3}$, Marianna Orlova ${ }^{1,2}$, Aurélie Cobat ${ }^{1,2}$, \\ Alexandre Alcaïs ${ }^{4,5,6}$, Marcelo Mira ${ }^{3}$, Erwin Schurr ${ }^{1,2} /+$ \\ ${ }^{1}$ McGill Centre for the Study of Host Resistance, Research Institute ${ }^{2}$ Department of Medicine and Human Genetics, \\ McGill University Health Centre, Montreal, Quebec, Canada ${ }^{3}$ Programa de Pós-Graduação em Ciências da Saúde, \\ Núcleo de Investigação Molecular Avançada, Pontifícia Universidade Católica do Paraná, Curitiba, PR, Brasil \\ ${ }^{4}$ Laboratory of Human Genetics of Infectious Diseases, Necker Branch, Institut National de la Santé et de la Recherche Médicale, \\ Paris, France ${ }^{5}$ Necker Medical School, University Paris Descartes, Paris, France ${ }^{6}$ Saint Giles Laboratory of \\ Human Genetics of Infectious Diseases, Rockefeller Branch, The Rockefeller University, New York, USA
}

Type-1 (T1R) and Type-2 (T2R) leprosy reactions (LR), which affect up to 50\% of leprosy patients, are aggressive inflammatory episodes of sudden onset and highly variable incidence across populations. LR are often diagnosed concurrently with leprosy, but more frequently occur several months after treatment onset. It is not uncommon for leprosy patients to develop recurring reactional episodes; however, they rarely undergo both types of LR. Today, $L R$ are the main cause of permanent disabilities associated with leprosy and represent a major challenge in the clinical management of leprosy patients. Although progress has been made in understanding the immunopathology of $L R$, the factors that cause a leprosy patient to suffer from LR are largely unknown. Given the impact that ethnic background has on the risk of developing LR, host genetic factors have long been suspected of contributing to LR. Indeed, polymorphisms in seven genes [Toll-like receptors (TLR)1, TLR2, nucleotide-binding oligomerisation domain containing 2, vitamin D receptor, natural resistance-associated macrophage protein 1, C4B and interleukin-6] have been found to be associated with one or more LR outcomes. The identification of host genetic markers with predictive value for $L R$ would have a major impact on nerve damage control in leprosy. In this review, we present the recent advances achieved through genetic studies of $L R$.

Key words: reversal reaction - type-1 leprosy reaction - erythema nodosum leprosum -

type-2 leprosy reaction - host genetic background - leprosy

Leprosy reactions (LR) are characterised by an intense and sudden activation/reactivation of the host immune/inflammatory responses that frequently affect the peripheral nerves. Population studies indicate that during the course of leprosy $16-56 \%$ of patients develop irreversible nerve function impairment (NFI) (Britton \& Lockwood 2004) that is mainly caused by LR. LR are a common cause of sensation/motor deficit and anatomical deformities in leprosy patients. In 2010, approximately $5.8 \%$ of newly detected leprosy cases worldwide presented grade- 2 disabilities at diagnosis (WHO 2011), a proportion that has been oscillating between 5-8\% since 2004. A substantial fraction of LR (30-40\%) are diagnosed concurrently with leprosy (Scollard et al. 1994, Ranque et al. 2007), which could partially explain the persistent detection of severe disability at the leprosy diagnosis. In fact, it is common for patients to seek medical attention in response to LR symptoms, with a subsequent diagnosis of leprosy. One current goal of leprosy control is a $35 \%$ global reduction in grade-2 disabilities (identified at the time of the leprosy diagnosis) by the end of 2015 (Pannikar 2009).

There are two major types of LR: type-1 reaction (T1R) or reversal reaction, and type-2 reaction (T2R)

+ Corresponding author: erwin.schurr@mcgill.ca Received 30 March 2012

Accepted 28 July 2012 or erythema nodosum leprosum. Patients may also develop Lucio's phenomenon (LP), which is also known as erythema necroticans and diffuse lepromatous leprosy (LL), erythema multiform and neuritis; however, these episodes represent a small proportion of all LR cases. Even though reactional episodes are characterized as acute outcomes, patients may also present a chronic reactional state, but rarely does the same patients suffer from different types of LR (Rea \& Sieling 1998, Moraes et al. 2001, Benard et al. 2009).

The clinical presentations of T1R and $\mathrm{T} 2 \mathrm{R}$ are distinct. However, both reaction types might share certain molecular control mechanisms, as several studies have shown that the cytokine profiles presented during T1R and T2R are similar (reviewed in Scollard et al. 2006). Still, such phenotypic similarities could be caused by the generalised immune dysregulation characteristics of both reaction types. Meanwhile, the existence of a common underlying control element in LR is a subject that is under discussion. When patients with either LR type were compared with non-reactional leprosy patients, the classical mediators of the cell-mediated immune response were observed at significantly higher levels, both systemically and in the local cutaneous lesions (Modlin et al. 1984, Sreenivasan et al. 1998, Moraes et al. 2001). A pro-inflammatory cytokine of particular interest is the tumour necrosis factor (TNF) as elevations of this cytokine have been observed in the serum and cutaneous lesions of T1R and T2R and in the nerve biopsies of T1R patients (reviewed in Scollard et al. 2006). 
$T I R$ - T1R LR are characterised by a delayed hypersensitivity to Mycobacterium leprae antigens (Gell \& Coombs type-IV reaction) and a sudden, abrupt increase in the cell-immune responsiveness in lesions; this increase can be maintained for an extended period of time (Ridley \& Radia 1981, Naafs 2000, Little et al. 2001). The main dermatome-pathological finding in T1R is an increase in the number of lymphocytes in the dermis with a loss of the normal granuloma structure. This breakdown of granuloma reduces the effectiveness of bacillary antigen containment. Additionally, Langhans giant cells may be observed in the later stages of T1R (Ridley \& Radia 1981, Walker \& Lockwood 2008). T1R affects $20-30 \%$ of leprosy patients (Roche et al. 1991, Scollard et al. 1994, Saunderson et al. 2000b, Ranque et al. 2007). The majority of these patients are classified in the borderline spectrum of the Ridley and Jopling (1966) (R \& J) scheme (Figure). T1R occurs more frequently than T2R (van Brakel et al. 2005). The clinical manifestations of T1R are an acute inflammation of pre-existing lesions, which can become erythematous, oedematous and infiltrated (Saunderson et al. 2000b). The peripheral nerves are frequently affected during the acute inflammatory process. Remarkably, new leprosy lesions may become apparent, most likely caused by an inflammatory response to previously undetected bacilli in the dermis (Rose \& Waters 1991). Oedema of the extremities may be present, but systemic complications are unusual (Walker \& Lockwood 2008). In addition to the border-

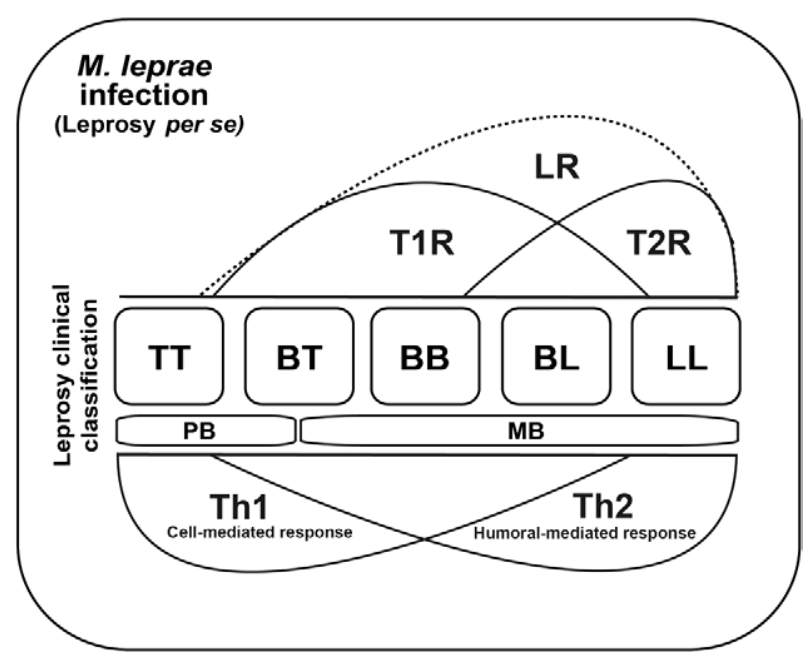

Schematic distribution of leprosy reaction (LR) across clinical spectrum of leprosy. The board represents patients infected by Mycobacterium leprae who developed clinical manifestation of the disease. In the middle a schematic distribution of Ridley and Joplin (1996) scheme and World Health Organization clinical classes of leprosy types is presented. The upper section shows the spread of the leprosy reaction types according to the risk rates across clinical leprosy classes. The bottom section symbolizes the corresponding cytokine profile, produced according to leprosy type. BB: borderline-borderline; BL: borderline-lepromatous; BT: borderline tuberculoid; LL: lepromatous-lepromatous; MB: multibacillary; PB: paucibacillary; T1R: type-1 reaction; T2R: type-2 reaction; Th1: T-helper 1; Th2: Thelper 2; TT: tuberculoid-tuberculoid. line clinical form of leprosy, important risk factors for T1R include the following: (i) age (individuals aged $>15$ years in southern Vietnam and $\geq 40$ years in Brazil are at increased risk) (Ranque et al. 2007, Sousa et al. 2007); (ii) a bacilloscopic index greater than 4+ (Saunderson et al. 2000b); (iii) an increased number of lesions at the leprosy diagnosis (van Brakel \& Khawas 1996, Kumar et al. 2004) and (iv) M. leprae DNA detection by polymerase chain reaction in the lesion biopsies (Sousa et al. 2007).

Epidemiological studies of T1R shows that in the vast majority of cases it is either diagnosed concurrently with leprosy or during the first two years after initiating leprosy multi-drug therapy (MDT) treatment (Scollard et al. 1994, Pocaterra et al. 2006). T1R may also occur many years after MDT completion; however, it can be difficult to distinguish between late-onset T1R and leprosy relapse (Waters 2001). The onset of T1R signs and symptoms is abrupt; therefore, immediate attention is necessary to reduce permanent NFI (van Brakel \& Khawas 1996). The up-regulation of pro-inflammatory cytokines such as TNF, interleukin (IL)-6, IL-1 $\beta$ and the chemokine induced protein-10 (IP-10) has been repeatedly observed in T1R patients in different populations (Sarno et al. 1991, Moraes et al. 1999, Oliveira et al. 1999, Stefani et al. 2009, Lockwood et al. 2011, Scollard et al. 2011). Even with adequate and timely treatment, up to $40 \%$ of T1R patients do not achieve complete lesion recovery (van Brakel \& Khawas 1996).

Initial T1R therapeutic interventions attempt to reduce the exacerbated immune response with cortisol and adrenocorticotropic hormone injections. Although initially effective, T1R relapses have been noted shortly after discontinuing such treatment (Naafs 2006). The exogenous corticoid therapy for T1R was established in the 50's (Roche et al. 1951). Today, the basic protocol is based on administering 30-40 mg/day of prednisolone, which is gradually reduced ( $5 \mathrm{mg} / 14$ days) as the patient's condition improves (Naafs 2006). Prolonged steroid use, four-nine months (Walker \& Lockwood 2008) and the accompanying adverse effects are two of the greatest challenges in managing T1R for both patients and clinicians. Interestingly, dysregulation of the cellular cortisol metabolism in leprosy lesions has been associated with T1R (Rook \& Baker 1999, Andersson et al. 2007). Circulation levels of insulin-like growth factor-I (IGF-I) have also been correlated with LR (Rodrigues et al. 2011); IGF-1 interacts with endogenous glucocorticoids and cytokines. These results point to the existence of an endogenous steroid metabolic pathway that regulates the inflammatory response in LR.

$T 2 R$ - The physiopathological mechanism responsible for T2R is widely unexplored. Classically, T2R has been considered an immune complex-mediated disorder (Gell \& Coombs type-III reaction) that resembles serum sickness (Wemambu et al. 1969, Hussain et al. 1995, Naafs 2006). In a divergent but not mutually exclusive view, T2R has been characterised as the consequence of both a transitory shift in the CD4/CD8 $\mathrm{T}$ cell ratio towards T-helper (Th) lymphocytes (Modlin et al. 1983, 1985) and the increased levels of pro-inflammatory cytokines, such as interferon- $\gamma$ (INF- $\gamma$ ), IL-1 $\beta$, TNF, IL- 6 and IL- 
12 , in patients who initially display a predominantly humoral immune response (Sarno et al. 1991, Barnes et al. 1992, Foss et al. 1993, Moraes et al. 1999, Kahawita \& Lockwood 2008, Stefani et al. 2009). However, the mechanism that triggers $\mathrm{T} 2 \mathrm{R}$ remains unclear. The histopathological findings in the skin biopsies of acute lesions demonstrate a predominance of neutrophils, eosinophils and mast cells. In chronic lesions, there is a reduction of neutrophils and an increase in the number of lymphocytes and plasmocytes (Mabalay et al. 1965). The clinical presentation of T2R includes generalised erythematous lesions, nodules and papules that may be superficial or deep, which may become ulcerative or necrotic. Some nodules reach chronicity, become painful and fibrotic and lead to scars. In contrast to T1R, the systemic effects of T2R are notorious and include high fever, oedema and a variety of complications, such nephritis, arthritis and iridocyclitis (Mabalay et al. 1965, Kahawita \& Lockwood 2008).

T2R mainly affects patients with multibacillary (MB) leprosy, which are classified at the borderline-lepromatous (BL)/LL pole of the disease spectrum (Figure). Patients presenting bacterial index higher than $4+$ in skin smears are at higher risk for T2R (Becx-Bleumink \& Berhe 1992, Manandhar et al. 1999). There is wide variation of $T 2 R$ prevalence across distinct geographical settings and ethnic boundaries. In Brazil, approximately $37 \%$ of BL and LL cases develop T2R, while in India, Nepal and Thailand, the proportion is between 19-26\% (Kahawita \& Lockwood 2008, Kahawita et al. 2008). The higher incidence of T2R in Brazil may reflect the relatively large proportion of MB leprosy cases in comparison with Southeast Asia. Follow-up studies have shown that the first T2R event is usually observed within the first three years after MDT implementation and that approximately one-third of all cases are diagnosed concurrently with leprosy (Manandhar et al. 1999, Saunderson et al. 2000a, Kumar et al. 2004, Feuth et al. 2008). A prospective study of BL and LL patients from India revealed that less than $10 \%$ of individuals who develop T2R presented a single episode, whereas $62 \%$ had chronic T2R (Pocaterra et al. 2006). In Ethiopia, 63\% of individuals had more than one T2R episode, while 37\% presented a single event (Saunderson et al. 2000a).

The reference treatment of T2R is also based on corticoid therapy, typically prednisolone at $40-60 \mathrm{mg} /$ day. However, TNF-suppressive drugs seem to be more effective. For example, the use of thalidomide has been extremely effective as a treatment for severe T2R (Tadesse et al. 2006). However, the use of this medication is restricted in several countries due to its teratogenicity (Lockwood \& Sinha 1999). Interestingly, thalidomide does not appear to interfere with the complement activation by M. leprae in vitro (Shannon et al. 2011) and its effectiveness is attributed to TNF suppression (Tadesse et al. 2006). The initial dose of thalidomide is $400 \mathrm{mg} /$ day, which is reduced as soon as possible to $300 \mathrm{mg} /$ day or less. Patients presenting with chronic T2R may be given $100 \mathrm{mg} / \mathrm{month}$ under clinical supervision (Walker et al. 2007). Two other TNF specific suppressors, the antibodies infliximab and etanercept, are also success- ful in arresting T2R in patients for whom previous drug therapies were ineffective (Faber et al. 2006, Ramien et al. 2011). Alternatively, pentoxifylline can be a drug of choice, as clinical studies have detected a reduction of INF- $\gamma$, TNF and IL-6 levels in the skin biopsies of T2R patients after pentoxifylline treatment (Sampaio et al. 1998, Moraes et al. 2000, Pocaterra et al. 2006).

$L P$ - LP is commonly considered an extensive and aggressive subtype of T2R; it was initially described by Lúcio and Alvarado (1852) and later reviewed by Latapi and Chavez-Zamora (1948). LP primarily affects LL and BL patients, particularly those of Latin ancestry (Costa Rica and Mexico) (Donner \& Shively 1967). However, cases outside Central America were reported on the West Coast of the United States of America, in South America and in Africa (Sehgal 2005).

The clinical features of LP include the development of acute, severe and necrotic lesions that are characterised by a diffuse cutaneous infiltrate and high bacillary load in the endothelium; in the advanced stages, extensive ulceration leading to secondary infection and sepsis may occur. LP differs from other LR outcomes by its frequent association with high mortality rates (Han et al. 2008). LP concomitant with other LR is rare; only a single, concomitant case of T2R and LP has been described (Benard et al. 2009). Histopathological studies show that IgG and/or C3 immunocomplex deposition in peripheral blood vessels of individuals affected by LP (Sehgal 2005). However, as LP incidence is low, systematic studies of its physiopathology are difficult. Recently, LP has been associated with a novel mycobacterium species (Mycobacterium lepromatosis sp.). The DNA analysis of autopsy samples from LP patients has detected sufficient variance in the sequenced regions to support the conclusion that this mycobacterial DNA is distinct from M. leprae (Han et al. 2008, 2009). These results are consistent with the presence of $M$. lepromatosis in the tissue biopsies of fatal LP cases from Mexico, Singapore and Ontario (Vera-Cabrera et al. 2011, Jessamine et al. 2012, Yang Han et al. 2012).

Host genetic background in LR - To date, a limited number of studies have investigated the impact of genetic variants controlling LR susceptibility. Although some results are inconclusive or suffer from the lack of replication, these studies have provided critical advances for the understanding of LR pathogenesis. Here, we present a summary of the genetic studies of LR phenotypes that were published before early 2012 .

Toll-like receptors (TLR) - TLR are single-pass transmembrane proteins that mediate cell signalling during the innate immune response. TLR are key mediators of host responsiveness to a diverse range of pathogenic structures leading to the activation of transcription factors and the secretion of pro-inflammatory cytokines and chemokines (Akira \& Takeda 2004, Alcais et al. 2005). Dysregulation of the TLR pathway has been associated with susceptibility to infectious disease and inflammatory disorders (Gay \& Gangloff 2007). The family members TLR1, 2 and 6 form heterodimers that are involved in M. leprae antigen recognition (Krutzik et al. 2003). 
$T L R 2$ - TLR2 plays a role in monocyte/macrophage activation and cytokine production in leprosy (Krutzik et al. 2005). Additionally, TLR2 expression by Schwann cells, the primary target of $M$. leprae, has been associated with increased apoptosis, which may indicate a mechanism by which the activation of innate immunity could contribute to nerve injury (Oliveira et al. 2003). The over stimulation of the TLR2 signalling cascade can result in massive TNF secretions, a hallmark of reactional episodes in LR patients. A significant reduction in both gene expression and protein levels of TLR2 and TLR4 has been noted during corticoid therapy in T1R patients (Walker et al. 2012).

A single nucleotide polymorphism (SNP), rs3804099 (alias: $+597 \mathrm{C} / \mathrm{T}$ ), and a microsatellite located between 162-100 bp upstream of the TLR2 start codon, were identified as genetic risk factors for T1R in an Ethiopian sample (Bochud et al. 2008). Of the 441 leprosy patients included in the study, 216 had LR data available. In a comparison of $66 \mathrm{~T} 1 \mathrm{R}$ patients with $17 \mathrm{~T} 2 \mathrm{R}$ and 133 neuritis patients, the rare allele T of rs 3804099 was found to be a protective factor for T1R [dominant model $\mathrm{p}=0.002$ odds ratio $(\mathrm{OR})=0.34(0.17-0.68)]$, while the 280 bp length microsatellite allele was associated with increased risk [recessive model $\mathrm{p}=0.001 \mathrm{OR}=5.83$ $(1.98-17.15)]$. Although the reported association is interesting, there is a potential bias in this study related to the selection of the control group, as it is preferable to include T1R-free patients who display borderline forms [borderline tuberculoid (BT), borderline-boderline and BL] of leprosy as controls. Epidemiological data indicate that polar form [tuberculoid-tuberculoid (TT) and LL] leprosy patients, as well as patients with generalised immune dysregulation (T2R), are less likely to develop T1R compared to borderline leprosy patients. Finally, in a stratified analysis by Ethiopian ethnicity, the association of TLR2 markers and T1R remained significant in two of three groups $(p<0.05)$. These are potentially interesting observations that need to be replicated in larger samples over a larger range of ethnic backgrounds.

TLR1 - TLR1, 2 and 6 are phylogenetically related (Johnson et al. 2007). TLR1 and TLR6 show high sequence similarity and tandem arrangement in the human genome; this similarity suggests a recent gene duplication event, while TLR 2 split off earlier in the evolutionary process (Roach et al. 2005). The heterodimer TLR1/ TLR2 is involved in the $M$. leprae antigen recognition (Krutzik et al. 2003, 2005), whereas TLR6 is related to $M$. leprae persistence in Schwann cells (Mattos et al. 2011). Hence, variations in these genes may variously modulate the innate immune system either negatively or positively; therefore an individual might be predisposed to mounting an ineffective or excessive inflammatory response.

TLR1 polymorphisms are associated with impaired signal transduction (Johnson et al. 2007, Wurfel et al. 2008). A TLRI non-synonymous polymorphism (rs5743618; I602S) is of particular interest. In HEK293, cells transfected with the two TLR1 alleles of the I602S polymorphism; the 602I allele regulated the basal level of NFKB activity and the NFKB response to $M$. tuberculosis extracts (Hawn et al. 2007). Independent stud- ies have shown that individuals who carry TLRI 602I produce higher levels of the cytokines IL-6, TNF and IL-1 $\beta$ (Hawn et al. 2007, Johnson et al. 2007, Misch et al. 2008), a common observation in patients during reactional episodes (Sarno et al. 1991, Moraes et al. 1999, Stefani et al. 2009).

To investigate the impact of the rs5743618 TLR1 polymorphism on LR, Misch et al. (2008) performed an association study in a Nepalese sample of 933 leprosy cases. The $\mathrm{G}$ allele (coding for the low response serine variant) showed a protective effect for the T1R cases when compared to a control group that comprised a mix of T2R and reaction-free patients with all forms of leprosy $[p=0.04, \mathrm{OR}=0.54(0.30-0.96)$, allelic model corrected by ethnicity, gender and age]. A trend in the association of the rs $5743618 \mathrm{G}$ allele and LL was also noted for these individuals $[p=0.11$ OR $=4.76(0.58-38.87)$, genotypic model] (Misch et al. 2008). The association of the serine allele with T1R protection is reasonable given that this variant drives a lower production of pro-inflammatory cytokines. Interestingly, the allele frequencies of rs5743618 vary greatly across populations. While the $\mathrm{G}$ allele (serine) is rare, or entirely absent in Africans and Asians, it is the major allele in populations of European descendant (Wong et al. 2010). The polymorphism has also been associated with susceptibility to clinical outcomes of malaria (Leoratti et al. 2008) and an altered immune response to BCG vaccination, with the same risk allele (Randhawa et al. 2011).

An additional study showed that the rs5743618 G allele was a protective factor against leprosy per se in two independent samples from India [combined analysis $\left.\mathrm{p}=5.710^{-8} ; \mathrm{OR}=0.31(0.20-0.48)\right]$ and one from Turkey $[\mathrm{p}=0.004$; OR $=0.48(0.29-0.80)]$ (Johnson et al. 2007, Wong et al. 2010). The role of the serine-coding allele as a protective factor for leprosy per se is intriguing, as the presence of the isoleucine allele supposedly guarantees an efficient translocation of TLR1 to the cell surface and the effective secretion of pro-inflammatory cytokines, thereby ensuring a better cell-mediated immune response against the infection. Alternatively, this data may suggest the TLR1/TLR2 pathway is one out of several systems potentially used by $M$. leprae for host immune evasion and macrophage invasion by the parasite. Whether the serine allele predisposes an individual to a subtype of leprosy, that increases the risk for T1R, or independently predisposes an individual to both leprosy per se and T1R is an unanswered question.

A second non-synonymous polymorphism of TLR1, rs 4833095, which causes a substitution of asparagine to serine $(\mathrm{N} 248 \mathrm{~S})$ in the external recognition site of the protein, was shown to be associated with LR susceptibility in a Bangladeshi population sample (Schuring et al. 2009). The serine-coding allele was described as a protective factor against T2R $[\mathrm{p}=0.04 ; \mathrm{OR}=0.40(0.16$ $0.99)]$. Interestingly, the asparagine in the leucine-rich repeat motif induces a diminished response to the mycobacterial cell wall components (Omueti et al. 2007). Although the sample size was large (842 leprosy cases), the analysis of T2R focused on only 11 cases. An additional problem with this study could be that the control group 
was mostly composed of paucibacillary leprosy cases, which are known not to be at risk for T2R. The authors also observed a trend for an association between the $\mathrm{S}$ allele and T1R. In the Bangladesh sample, the minor allele frequency for rs 5743618 was close to that of the Nepalese sample ( 0.05); however, no association was observed between the I602S polymorphism and T1R $(\mathrm{p}=0.54)$.

Nucleotide-binding oligomerisation domain-like receptors (NLR) - NLR comprise a family of cytosolic pattern recognition receptors that are part of the innate immune system. Nucleotide-binding oligomerisation domain containing 2 (NOD2) is a recognised member of this family (Franchi et al. 2009). There is evidence that NOD2 agonists synergise with TLR ligands, particularly those for TLR4 and TLR9, to induce pathways that lead to the production of pro-inflammatory cytokines (IL12 and INF- $\gamma$ ) and anti-microbial molecules (Fritz et al. 2005, Tada et al. 2005). The muramyl dipeptide NOD2 agonist mimics the bacterial peptidoglycan moiety and induces strong cell-mediated immunity that resembles delayed-type hypersensitivity (Tada et al. 2005). Importantly, delayed-type hypersensitivity to M. leprae antigens is a recognised event in T1R.

NOD2 is a Crohn's disease (CD) susceptibility gene (Ogura et al. 2001, Hugot et al. 2001, Noguchi et al. 2009). This finding has led to the suggestion that Mycobacterium avium subs. paratuberculosis (MAP) may be part of the aetiology of (at least) a subset of CD patients (Behr $\&$ Schurr 2006). The latter suggestion has received additional support by the striking overlap of susceptibility genes between CD and leprosy (Schurr \& Gros 2009). In fact, NOD2 polymorphisms have been associated with leprosy per se in Chinese and Nepalese patients (Zhang et al. 2009, Berrington et al. 2010).

NOD2 - Variations in the NOD2 gene were analysed in the same Nepalese sample that had been used for the TLR1 study (Misch et al. 2008). The SNPs selected for genotyping were: (i) tag SNPs in the European and Chinese HapMap samples, capturing the genetic variation of NOD2 plus $50 \mathrm{~kb}$ up and down-stream of the gene, and (ii) known, rare, non-synonymous variants within the NOD2 (Berrington et al. 2010). A total of 32 SNPs were analysed and multiple signals of association with leprosy per se (8/32), T1R (7/32) and T2R (7/32) were observed. However, strong linkage disequilibrium (LD) across the entire NOD2 gene suggested that the signals of association may not be completely independent. Remarkably, two SNPs (rs2287195 and rs8044354) were associated with all three studied phenotypes. The best $\mathrm{p}$ values for these associations are as follows: leprosy per se $[\mathrm{p}$ $=0.001 ; \mathrm{OR}=2.29(1.43-3.68)$ and $\mathrm{p}=0.001 ; \mathrm{OR}=2.17$ (1.36-3.46)], T1R $[\mathrm{p}=0.013 ; \mathrm{OR}=0.74(0.58-0.95)$ and $\mathrm{p}=0.005 ; \mathrm{OR}=0.74(0.59-0.92)]$ and $\mathrm{T} 2 \mathrm{R}[\mathrm{p}=0.015$; $\mathrm{OR}=1.93(1.14-3.30)$ and $\mathrm{p}=0.001 ; \mathrm{OR}=2.83(1.52-$ $5.28)]$, respectively. These variants are in strong $\operatorname{LD}\left(\mathrm{r}^{2}\right.$ $=0.6-0.69)$ and the risk allele for T2R is the protective allele for T1R and vice versa for both of SNPs. This finding may indicate a cryptic association between the SNPs and leprosy type, as a non-random distribution of LR is observed across the R \& J scale. Surprisingly, only SNP rs1131716 was associated with an increased risk for lepromatous leprosy $[\mathrm{p}=0.013 \mathrm{OR}=2.01(1.12-3.76)]$. Interestingly, rs1131716 is a non-synonymous polymorphism (P35L) in SLIC1 exon 1. A functional study showed that SLIC1 immunoprecipitated with PSGL1 (Schaff et al. 2008), the principle glycoprotein responsible for the interaction of memory $\mathrm{T}$ cells with $\mathrm{E}$ and P-selectins. In the skin lesions of a number of skin disorders, including psoriasis, PSGL1 modulates the adhesive properties of leukocytes and $\mathrm{T}$ cell infiltrates in the peripheral tissues (Fuhlbrigge et al. 1997, Nestle et al. 2009).

IL6 - IL-6 is a pleiotropic cytokine first recognised for its ability to induce antibody production. However, the role of IL-6 is much broader and this cytokine is a key player in the acute phase response to infection. In addition to being produced by a wide spectrum of cell types, including $\mathrm{T}$ and $\mathrm{B}$ cells, macrophages, activated monocytes, mast cells, neutrophils and eosinophils, IL-6 can exert its effects on any of these cells. Based on IL-6 potent pro-inflammatory effect associated with its capacity to induce antibody production, several mechanisms that support a role of IL-6 in T2R pathogenesis have been proposed.

A gene expression analysis using peripheral blood mononuclear cells from reactional vs. non-reactional leprosy patients revealed that $I L-6$ was over-expressed by T1R and T2R patients. When skin biopsies were analysed, an increased expression of IL6 was detected in samples from T2R and T1R patients, whereas in nonreactional individuals, $I L-6$ mRNA was only detected in the lesions from TT/BT patients (Moraes et al. 1999). Independent studies revealed that circulating levels of IL-6 were higher in the T2R patients than in the nonreactional leprosy cases (Belgaumkar et al. 2007, Stefani et al. 2009). Stefani et al. (2009) analysed 27 plasma factors and found that IL- 6 was the only biomarker that was elevated in T1R and T2R when compared to the leprosy patients without reactions.

In groups matched by leprosy $\mathrm{R} \& \mathrm{~J}$ type, our study found higher IL-6 plasma levels in T1R and T2R cases when compared to patients with no reaction. Interestingly, the IL-6 levels were strikingly higher in T2R compared to T1R cases $\left(p=2.410^{-7}\right)$ (Sousa et al. 2012). In the same study, the impact of the genetic variants of IL6 on LR susceptibility was investigated in a population sample of 409 newly diagnosed leprosy cases. Tag SNPs were selected to cover the IL6 gene and its promoter region. No association was observed between the IL6 markers and T1R. However, three tag SNPs (rs2069832, rs2069840 and rs2069845) were significantly associated with T2R when the cases were compared to reaction-free patients from the lepromatous pole of the disease $[\mathrm{p}=0.002$; OR $=4.00(1.64-9.76) ; \mathrm{p}=0.027 ; \mathrm{OR}=0.44(0.22-0.91)$ and $\mathrm{p}=0.044 ; \mathrm{OR}=1.92(1.02-3.63)$, respectively]. A comprehensive search of the HapMap database revealed that SNP rs2069832 was tagging a bin containing the variant rs1800795, a known functional polymorphism localised at a negative regulatory domain in the promoter region of IL6 (Ray et al. 1990, Fishman et al. 1998). Further analysis revealed that SNP rs1800795 was indeed associated with T2R $[\mathrm{p}=0.005 ; \mathrm{OR}=3.71(1.47-9.34)]$. A 
multivariate analysis revealed independent signals for rs1800795 and rs2069840. The haplotypic analysis that included these two SNPs showed that the presence of the risk allele "C" at both loci was associated with T2R susceptibility $[\mathrm{p}=0.02 ; \mathrm{OR}=3.17$ (1.21-8.29), dominant model]. Testing for an association between IL6 genotypes and IL-6 plasma levels revealed that the presence of the "G" allele of rs2069840, which is associated with protection from T2R, correlated with lower IL-6 plasma levels in a sub-sample of 33 T2R affected individuals ( $\mathrm{p}$ $=0.04$ ) (Sousa et al. 2012). Together, these results support an important role of IL-6 in the T2R pathogenesis.

IL6 polymorphisms are also associated with several chronic, autoimmune and inflammatory diseases, including rheumatoid arthritis (Pascual et al. 2000), juvenile arthritis (Fishman et al. 1998), CD (Sawczenko et al. 2005, Guerreiro et al. 2009), periodontitis (Trevilatto et al. 2003, Nibali et al. 2009) and Parkinson's disease (San Luciano et al. 2012). Interestingly, IL6 genetic variants are associated with susceptibility to leishmaniasis (Castellucci et al. 2006) and the growth of Chlamydia pneumoniae in macrophages (Poikonen et al. 2009).

$C 4 B$ - A widely accepted assumption is that $\mathrm{T} 2 \mathrm{R}$ is an immune complex-mediated disease. The $\mathrm{C} 4 \mathrm{~b}$ and $\mathrm{C} 3 \mathrm{~b}$ factors of the complement system are known to induce the opsonisation of microbial components for efficient uptake by macrophages (Carroll 1998). A possible role for the complement system in immune evasion by M. leprae was suggested by the co-localisation of $\mathrm{C} 3$ and PGL-1 in the lipid rafts of dendritic cell membranes (Callegaro-Filho et al. 2010). A recent study showed a possible feedback mechanism in which $\mathrm{C} 3 \mathrm{~b}$ and $\mathrm{C} 4 \mathrm{~b}$ reduced the secretion of the pro-inflammatory chemokine IP-10 in peripheral blood after being stimulated with lipopolysaccharide and IFN $\beta$ (Takeda et al. 2012). In a Brazilian sample, the $\mathrm{C}^{2} \mathrm{~B}^{*} \mathrm{Q} 0$ allele was associated with risk to leprosy per se when cases were compared to healthy controls $\left(\mathrm{p}=2.710^{-5}\right)$. Interestingly, the $\mathrm{C} 4 \mathrm{~B} * \mathrm{Q} 0$ allele frequency was significantly higher among T2R cases (22 individuals) when compared with the LL patients who had no reaction (6) $(\mathrm{p}=0.006)$ (de Messias et al. 1993). These findings suggest that the complement system may affect both the phagocytosis during the reactivation/exacerbation of the inflammatory response in $\mathrm{T} 2 \mathrm{R}$ and the stimulation of cellular immune responses, possibly through IP-10-related pathways.

Vitamin D receptor (VDR) - The active form of vitamin $\mathrm{D}\left(1,25(\mathrm{OH})_{2} \mathrm{D}_{3}\right)$ is a known regulator of the host immune response against infection (White 2008) and genetic polymorphisms of the $V D R$ gene are associated with both tuberculosis and leprosy (reviewed in Mira 2006). In a Nepalese sample, the $T$ allele of the SNP rs2228570 (VDR-FokI) was a statistically significant risk factor for T1R $[\mathrm{p}=0.032$; OR $=1.31(1.01$ 1.68)] (Sapkota et al. 2010). Interestingly, the activation of human macrophages through TLR2/1 signalling upregulates $V D R$ expression, leading to the secretion of the antimicrobial peptide cathelicidin and the killing of $M$. tuberculosis (Liu et al. 2006). Likewise, active vitamin $\mathrm{D}$ robustly stimulates the expression of $N O D 2$ in the primary human monocyte and epithelial cells from CD patients through ligation with VDR (Wang et al. 2010). These observations point to the existence of a common pathway for the host immune defence against mycobacteria (Verway et al. 2010).

Natural resistance-associated macrophage protein 1 (NRAMP1) - NRAMP1, also known as SCL11A1, is a multi-pass membrane protein that mediates the transport/transition of divalent metals (iron and manganese). In human blood, polymorphonuclear leukocytes are the most abundant site of NRAMP1 mRNA expression (Canonne-Hergaux et al. 2002). Nrampl controls susceptibility to several intracellular macrophage pathogens in the mouse (Vidal et al. 1995, Govoni \& Gros 1998). Studies of the human homologue NRAMPI have resulted in evidence of both linkage and association of the region/ gene with leprosy phenotypes (Abel et al. 1998, Alcais et al. 2000, Meisner et al. 2001). A meta-analysis of 36 studies confirmed the association of NRAMP1 polymorphism with tuberculosis susceptibility ( $\mathrm{Li}$ et al. 2011). Studies in carefully selected patient populations showed a strong association of $N R A M P 1$ with primary tuberculosis (Greenwood et al. 2000, Malik et al. 2005). Susceptibility to other infectious and immune-mediated diseases, such as leishmaniasis (Mohamed et al. 2004), human immunodeficiency virus infection (Marquet et al. 1999), CD (presence of MAP DNA) (Kojima et al. 2001, Stewart et al. 2010) and systemic lupus erythematous (Pedroza et al. 2011) has also been related to NRAMPI variants.

A recent study in a Brazilian sample of 201 leprosy cases revealed that the SNP $274 \mathrm{C} / \mathrm{T}$ of NRAMPlis associated with LR. An unusually high frequency of LR was observed in this population sample. However, the authors did not clarify if LR was a criterion of sample selection in the study (Teixeira et al. 2010). The presence of the "C" allele was a risk factor for T1R $\left(\mathrm{p}_{\text {fisher }}=0.03\right)$, while being protective for $\mathrm{T} 2 \mathrm{R}\left(\mathrm{p}_{\text {fisher }}=0.04\right)$. Interestingly, this is the same polymorphism that has been shown to be a major risk factor for primary tuberculosis in a paediatric sample of mixed ethnic background (Malik et al. 2005).

Over the past decade, technological advances in genetic research improved our understanding of the molecular basis of leprosy pathogenesis (Alcais et al. 2000, 2007, Mira et al. 2003, 2004, Ranque et al. 2005, Zhang et al. 2009, Alter et al. 2010, Orlova et al. 2011). However, only recently has the focus of the scientific community turned towards deciphering the mechanisms behind LR.

The first genetic association studies of LR led to exciting results. However, classic case-control designs raise the problem of how to properly select comparable groups when studying the LR phenotype. Defining cases and controls represents a crucial and challenging step prior to the data analysis. Only individuals at equal risk for the outcome should be selected as controls, as the inclusion of patients with T2R that rarely develop T1R or patients with polar leprosy forms (TT and LL) as controls for T1R can introduce bias. Given the striking differences in the risk for T1R across leprosy forms, it is possible that polar form patients develop T1R by different mechanisms than borderline patients. Likewise, patients with tuberculoid forms of leprosy (TT, BT) should not be included as con- 
trols in a T2R study, as such individuals are not known to develop T2R. In addition, the co-variables that impact at the risk for LR (e.g., age at leprosy onset) add heterogeneity to both the case and the control group and should be accounted for in the multivariate or stratified analyses. Finally, the genetic association studies performed in LR lack replication. This issue is important, as only wellreplicated results can provide the basis for functional follow-ups to the genetic findings. The functional validation of the replicated genetic associations will provide better insight into the genetic component of LR and help to unravel the mechanisms underlying this immune dysfunction. Although LR will continue to be a public health problem for many years, the knowledge of the predictive factors for LR will provide the means for the timely identification of at-risk leprosy patients. Additionally, LR can serve as a model for immune dysregulation when studying other infectious and inflammatory diseases.

\section{REFERENCES}

Abel L, Sanchez FO, Oberti J, Thuc NV, Hoa LV, Lap VD, Skamene E, Lagrange PH, Schurr E 1998. Susceptibility to leprosy is linked to the human NRAMP1 gene. J Infect Dis 177: 133-145.

Akira S, Takeda K 2004. Toll-like receptor signalling. Nat Rev Immunol 4: 499-511.

Alcais A, Alter A, Antoni G, Orlova M, Van Thuc N, Singh M, Vanderborght PR, Katoch K, Mira MT, Thai VH, Huong NT, Ba NN, Moraes M, Mehra N, Schurr E, Abel L 2007. Stepwise replication identifies a low-producing lymphotoxin-[alpha] allele as a major risk factor for early-onset leprosy. Nat Genet 39: 517-522.

Alcais A, Mira M, Casanova JL, Schurr E, Abel L 2005. Genetic dissection of immunity in leprosy. Curr Opin Immunol 17: 44-48.

Alcais A, Sanchez FAO, Thuc NAV, Lap VAD, Oberti J, Lagrange PAH, Schurr E, Abel L 2000. Granulomatous reaction to intradermal injection of lepromin (Mitsuda reaction) is linked to the human NRAMP1 gene in Vietnamese leprosy sibships. $J$ Infect Dis 181: 302-308.

Alter A, de Leseleuc L, Van Thuc N, Thai VH, Huong NT, Ba NN, Cardoso CC, Grant AV, Abel L, Moraes MO, Alcais A, Schurr E 2010. Genetic and functional analysis of common MRC1 exon 7 polymorphisms in leprosy susceptibility. Hum Genet 127: 337-348.

Andersson AK, Atkinson SE, Khanolkar-Young S, Chaduvula M, Jain S, Suneetha L, Suneetha S, Lockwood DN 2007. Alteration of the cortisol-cortisone shuttle in leprosy type 1 reactions in leprosy patients in Hyderabad, India. Immunol Lett 109: 72-75.

Barnes PF, Chatterjee D, Brennan PJ, Rea TH, Modlin RL 1992. Tumor necrosis factor production in patients with leprosy. Infect Immun 60: 1441-1446.

Becx-Bleumink M, Berhe D 1992. Occurrence of reactions, their diagnosis and management in leprosy patients treated with multidrug therapy; experience in the leprosy control program of the All Africa Leprosy and Rehabilitation Training Center (ALERT) in Ethiopia. Int J Lepr Other Mycobact Dis 60: 173-184.

Behr MA, Schurr E 2006. Mycobacteria in Crohn's disease: a persistent hypothesis. Inflamm Bowel Dis 12: 1000-1004.

Belgaumkar VA, Gokhale NR, Mahajan PM, Bharadwaj R, Pandit DP, Deshpande S 2007. Circulating cytokine profiles in leprosy patients. Lepr Rev 78: 223-230.

Benard G, Sakai-Valente NY, Bianconcini Trindade MA 2009. Concomitant Lucio phenomenon and erythema nodosum in a leprosy patient: clues for their distinct pathogeneses. Am J Dermatopathol 31: 288-292.

Berrington WR, Macdonald M, Khadge S, Sapkota BR, Janer M, Hagge DA, Kaplan G, Hawn TR 2010. Common polymorphisms in the NOD2 gene region are associated with leprosy and its reactive states. J Infect Dis 201: 1422-1435.

Bochud PY, Hawn Thomas ÂR, Siddiqui MÂR, Saunderson P, Britton S, Abraham I, Argaw AzebÂ T, Janer M, Zhao LueÂP, Kaplan G, Aderem A 2008. Toll-like receptor 2 (TLR2) polymorphisms are associated with reversal reaction in leprosy. J Infect Dis 197: 253-261.

Britton WJ, Lockwood DN 2004. Leprosy. Lancet 363: 1209-1219.

Callegaro-Filho D, Shrestha N, Burdick AE, Haslett PA 2010. A potential role for complement in immune evasion by Mycobacterium leprae. J Drugs Dermatol 9: 1373-1382.

Canonne-Hergaux F, Calafat J, Richer E, Cellier M, Grinstein S, Borregaard N, Gros P 2002. Expression and subcellular localization of NRAMP1 in human neutrophil granules. Blood 100: 268-275.

Carroll MC 1998. The role of complement and complement receptors in induction and regulation of immunity. Аnпu Rev Immunol 16: 545-568.

Castellucci L, Menezes E, Oliveira J, Magalhaes A, Guimaraes LH, Lessa M, Ribeiro S, Reale J, Noronha EF, Wilson ME, Duggal P, Beaty TH, Jeronimo S, Jamieson SE, Bales A, Blackwell JM, de Jesus AR, Carvalho EM 2006. IL-6-174 G/C promoter polymorphism influences susceptibility to mucosal, but not localized cutaneous leishmaniasis in Brazil. J Infect Dis 194: 519-527.

de Messias IJ, Santamaria J, Brenden M, Reis A, Mauff G 1993. Association of C4B deficiency (C4B*Q0) with erythema nodosum in leprosy. Clin Exp Immunol 92: 284-287.

Donner RS, Shively JA 1967. The "Lucio phenomenon" in diffuse leprosy. Ann Intern Med 67: 831-836.

Faber WR, Jensema AJ, Goldschmidt WF 2006. Treatment of recurrent erythema nodosum leprosum with infliximab. $N$ Engl J Med 355: 739.

Feuth M, Brandsma JW, Faber WR, Bhattarai B, Feuth T, Anderson AM 2008. Erythema nodosum leprosum in Nepal: a retrospective study of clinical features and response to treatment with prednisolone or thalidomide. Lepr Rev 79: 254-269.

Fishman D, Faulds G, Jeffery R, Mohamed-Ali V, Yudkin JS, Humphries S, Woo P 1998. The effect of novel polymorphisms in the interleukin-6 (IL-6) gene on IL-6 transcription and plasma IL-6 levels and an association with systemic-onset juvenile chronic arthritis. J Clin Invest 102: 1369-1376.

Foss NT, de Oliveira EB, Silva CL 1993. Correlation between TNF production, increase of plasma C-reactive protein level and suppression of T lymphocyte response to concanavalin A during erythema nodosum leprosum. Int J Lepr Other Mycobact Dis 61: 218-226.

Franchi L, Warner N, Viani K, Nunez G 2009. Function of Nod-like receptors in microbial recognition and host defense. Immunol Rev 227: $106-128$.

Fritz JH, Girardin SE, Fitting C, Werts C, Mengin-Lecreulx D, Caroff M, Cavaillon JM, Philpott DJ, Adib-Conquy M 2005. Synergistic stimulation of human monocytes and dendritic cells by Toll-like receptor 4 and NOD1 and NOD2-activating agonists. Eur J Immunol 35: 2459-2470.

Fuhlbrigge RC, Kieffer JD, Armerding D, Kupper TS 1997. Cutaneous lymphocyte antigen is a specialized form of PSGL-1 expressed on skin-homing T cells. Nature 389: 978-981.

Gay NJ, Gangloff M 2007. Structure and function of Toll receptors and their ligands. Annu Rev Biochem 76: 141-165. 
Govoni G, Gros P 1998. Macrophage NRAMP1 and its role in resistance to microbial infections. Inflamm Res 47: 277-284.

Greenwood CM, Fujiwara TM, Boothroyd LJ, Miller MA, Frappier D, Fanning EA, Schurr E, Morgan K 2000. Linkage of tuberculosis to chromosome 2q35 loci including NRAMP1 in a large aboriginal Canadian family. Am J Hum Genet 67: 405-416.

Guerreiro CS, Ferreira P, Tavares L, Santos PM, Neves M, Brito M, Cravo M 2009. Fatty acids, IL-6 and TNF-alpha polymorphisms: an example of nutrigenetics in Crohn's disease. Am J Gastroenterol 104: 2241-2249.

Han XY, Seo Y-H, Sizer KC, Schoberle T, May GS, Spencer JS, Li W, Nair RG 2008. A new Mycobacterium species causing diffuse lepromatous leprosy. Am J Clin Pathol 130: 856-864.

Han XY, Sizer KC, Thompson EJ, Kabanja J, Li J, Hu P, GomezValero L, Silva FJ 2009. Comparative sequence analysis of $M y$ cobacterium leprae and the new leprosy-causing Mycobacterium lepromatosis. J Bacteriol 191: 6067-6074.

Hawn TR, Misch EA, Dunstan SJ, Thwaites GE, Lan NT, Quy HT, Chau TT, Rodrigues S, Nachman A, Janer M, Hien TT, Farrar JJ, Aderem A 2007. A common human TLR1 polymorphism regulates the innate immune response to lipopeptides. Eur J Immunol 37: 2280-2289.

Hugot JP, Chamaillard M, Zouali H, Lesage S, Cezard JP, Belaiche J, Almer S, Tysk C, O'Morain CA, Gassull M, Binder V, Finkel Y, Cortot A, Modigliani R, Laurent-Puig P, Gower-Rousseau C, Macry J, Colombel JF, Sahbatou M, Thomas G 2001. Association of NOD2 leucine-rich repeat variants with susceptibility to Crohn's disease. Nature 411: 599-603.

Hussain R, Lucas SB, Kifayet A, Jamil S, Raynes J, Uqaili Z, Dockrell HM, Chiang TJ, McAdam KP 1995. Clinical and histological discrepancies in diagnosis of ENL reactions classified by assessment of acute phase proteins SAA and CRP. Int J Lepr Other Mycobact Dis 63: 222-230.

Jessamine PG, Desjardins M, Gillis T, Scollard D, Jamieson F, Broukhanski G, Chedore P, McCarthy A 2012. Leprosy-like illness in a patient with Mycobacterium lepromatosis from Ontario, Canada. J Drugs Dermatol 11: 229-233.

Johnson CM, Lyle EA, Omueti KO, Stepensky VA, Yegin O, Alpsoy E, Hamann L, Schumann RR, Tapping RI 2007. Cutting edge: a common polymorphism impairs cell surface trafficking and functional responses of TLR1, but protects against leprosy. J Immunol 178: 7520-7524.

Kahawita IP, Lockwood DN 2008. Towards understanding the pathology of erythema nodosum leprosum. Trans $R$ Soc Trop Med Hyg 102: 329-337.

Kahawita IP, Walker SL, Lockwood DNJ 2008. Leprosy type 1 reactions and erythema nodosum leprosum. An bras Dermatol 83: 75-82.

Kojima Y, Kinouchi Y, Takahashi S, Negoro K, Hiwatashi N, Shimosegawa T 2001. Inflammatory bowel disease is associated with a novel promoter polymorphism of natural resistance-associated macrophage protein 1 (NRAMPI) gene. Tissue Antigens 58: 379-384.

Krutzik SR, Ochoa MT, Sieling PA, Uematsu S, Ng YW, Legaspi A, Liu PT, Cole ST, Godowski PJ, Maeda Y, Sarno EN, Norgard MV, Brennan PJ, Akira S, Rea TH, Modlin RL 2003. Activation and regulation of Toll-like receptors 2 and 1 in human leprosy. Nat Med 9: 525-532.

Krutzik SR, Tan B, Li H, Ochoa MT, Liu PT, Sharfstein SE, Graeber TG, Sieling PA, Liu YJ, Rea TH, Bloom BR, Modlin RL 2005. TLR activation triggers the rapid differentiation of monocytes into macrophages and dendritic cells. Nat Med 11: 653-660.

Kumar B, Dogra S, Kaur I 2004. Epidemiological characteristics of leprosy reactions: 15 years experience from North India. Int $J$ Lepr Other Mycobact Dis 72: 125-133.
Latapi F, Chavez-Zamora A 1948. The“spotted" leprosy of Lucio: an introduction to its clinical and histological study. Int J Lepr 16: 421-437.

Leoratti FM, Farias L, Alves FP, Suarez-Mutis MC, Coura JR, Kalil J, Camargo EP, Moraes SL, Ramasawmy R 2008. Variants in the Toll-like receptor signaling pathway and clinical outcomes of malaria. J Infect Dis 198: 772-780.

Li X, Yang Y, Zhou F, Zhang Y, Lu H, Jin Q, Gao L 2011. SLC11A1 (NRAMP1) polymorphisms and tuberculosis susceptibility: updated systematic review and meta-analysis. PLOS ONE 6: e15831.

Little D, Khanolkar-Young S, Coulthart A, Suneetha S, Lockwood DN 2001. Immunohistochemical analysis of cellular infiltrate and gamma interferon, interleukin-12 and inducible nitric oxide synthase expression in leprosy type 1 (reversal) reactions before and during prednisolone treatment. Infect Immun 69: 3413-3417.

Liu PT, Stenger S, Li H, Wenzel L, Tan BH, Krutzik SR, Ochoa MT, Schauber J, Wu K, Meinken C, Kamen DL, Wagner M, Bals R, Steinmeyer A, Zugel U, Gallo RL, Eisenberg D, Hewison M, Hollis BW, Adams JS, Bloom BR, Modlin RL 2006. Toll-like receptor triggering of a vitamin D-mediated human antimicrobial response. Science 311: 1770-1773.

Lockwood DN, Sinha HH 1999. Pregnancy and leprosy: a comprehensive literature review. Int J Lepr Other Mycobact Dis 67: 6-12.

Lockwood DN, Suneetha L, Sagili KD, Chaduvula MV, Mohammed I, van Brakel W, Smith WC, Nicholls P, Suneetha S 2011. Cytokine and protein markers of leprosy reactions in skin and nerves: baseline results for the North Indian INFIR cohort. PLoS Negl Trop Dis 5: e1327.

Lucio R, Alvarado Y 1852. Opusculo sobre el mal de San Lazaro o elefanciasis de los Griegos, M Murguia y Cia, Mexico, 53 pp.

Mabalay MC, Helwig EB, Tolentino JG, Binford CH 1965. The histopathology and histochemistry of erythema nodosum leprosum. Int J Lepr 33: 28-49.

Malik S, Abel L, Tooker H, Poon A, Simkin L, Girard M, Adams GJ, Starke JR, Smith KC, Graviss EA, Musser JM, Schurr E 2005. Alleles of the NRAMP1 gene are risk factors for pediatric tuberculosis disease. Proc Natl Acad Sci USA 102: 12183-12188.

Manandhar R, Le Master JW, Roche PW 1999. Risk factors for erythema nodosum leprosum. Int J Lepr Other Mycobact Dis 67: 270-278.

Marquet S, Sanchez FO, Arias M, Rodriguez J, Paris SC, Skamene E, Schurr E, Garcia LF 1999. Variants of the human NRAMP1 gene and altered human immunodeficiency virus infection susceptibility. J Infect Dis 180: 1521-1525.

Mattos KA, Oliveira VG, D'Avila H, Rodrigues LS, Pinheiro RO, Sarno EN, Pessolani MC, Bozza PT 2011. TLR6-driven lipid droplets in Mycobacterium leprae-infected Schwann cells: immunoinflammatory platforms associated with bacterial persistence. J Immunol 187: 2548-2558.

Meisner SJ, Mucklow S, Warner G, Sow SO, Lienhardt C, Hill AV 2001. Association of NRAMP1 polymorphism with leprosy type, but not susceptibility to leprosy per se in west Africans. Am J Trop Med Hyg 65: 733-735.

Mira MT 2006. Genetic host resistance and susceptibility to leprosy. Microbies Infection 8: 1124-1131.

Mira MT, Alcais A, Nguyen VT, Moraes MO, Di Flumeri C, Vu HT, Mai CP, Nguyen TH, Nguyen NB, Pham XK, Sarno EN, Alter A, Montpetit A, Moraes ME, Moraes JR, Dore C, Gallant CJ, Lepage P, Verner A, Van de Vosse E, Hudson TJ, Abel L, Schurr E 2004. Susceptibility to leprosy is associated with PARK2 and PACRG. Nature 427: 636-640. 
Mira MT, Alcais A, Van Thuc N, Thai VH, Huong NT, Ba NN, Verner A, Hudson TJ, Abel L, Schurr E 2003. Chromosome 6q25 is linked to susceptibility to leprosy in a Vietnamese population. Nat Genet 33: 412-415.

Misch EA, Macdonald M, Ranjit C, Sapkota BR, Wells RD, Siddiqui MR, Kaplan G, Hawn TR 2008. Human TLR1 deficiency is associated with impaired mycobacterial signaling and protection from leprosy reversal reaction. PLoS Negl Trop Dis 2: e231.

Modlin RL, Bakke AC, Vaccaro SA, Horwitz DA, Taylor CR, Rea TH 1985. Tissue and blood T-lymphocyte subpopulations in erythema nodosum leprosum. Arch Dermatol 121: 216-219.

Modlin RL, Gebhard JF, Taylor CR, Rea TH 1983. In situ characterization of $\mathrm{T}$ lymphocyte subsets in the reactional states of leprosy. Clin Exp Immunol 53: 17-24.

Modlin RL, Hofman FM, Horwitz DA, Husmann LA, Gillis S, Taylor CR, Rea TH 1984. In situ identification of cells in human leprosy granulomas with monoclonal antibodies to interleukin 2 and its receptor. J Immunol 132: 3085-3090.

Mohamed HS, Ibrahim ME, Miller EN, White JK, Cordell HJ, Howson JM, Peacock CS, Khalil EA, El Hassan AM, Blackwell JM 2004. SLC11A1 (formerly NRAMP1) and susceptibility to visceral leishmaniasis in The Sudan. Eur J Hum Genet 12: 66-74.

Moraes MO, Sampaio EP, Nery JA, Saraiva BC, Alvarenga FB, Sarno EN 2001. Sequential erythema nodosum leprosum and reversal reaction with similar lesional cytokine mRNA patterns in a borderline leprosy patient. Br J Dermatol 144: 175-181.

Moraes MO, Sarno EN, Almeida AS, Saraiva BC, Nery JA, Martins RC, Sampaio EP 1999. Cytokine mRNA expression in leprosy: a possible role for interferon-gamma and interleukin-12 in reactions (RR and ENL). Scand J Immunol 50: 541-549.

Moraes MO, Sarno EN, Teles RM, Almeida AS, Saraiva BC, Nery JA, Sampaio EP 2000. Anti-inflammatory drugs block cytokine mRNA accumulation in the skin and improve the clinical condition of reactional leprosy patients. J Invest Dermatol 115: 935-941.

Naafs B 2000. Viewpoint: leprosy after the year 2000. Trop Med Int Health 5: 400-403.

Naafs B 2006. Treatment of leprosy: science or politics? Trop Med Int Health 11: 268-278.

Nestle FO, Kaplan DH, Barker J 2009. Psoriasis. N Engl J Med 361: 496-509.

Nibali L, D’Aiuto F, Donos N, Griffiths GS, Parkar M, Tonetti MS, Humphries SE, Brett PM 2009. Association between periodontitis and common variants in the promoter of the interleukin- 6 gene. Cytokine 45: 50-54

Noguchi E, Homma Y, Kang X, Netea MG, Ma X 2009. A Crohn's disease-associated NOD2 mutation suppresses transcription of human IL-10 by inhibiting activity of the nuclear ribonucleoprotein hnRNP-A1. Nat Immunol 10: 471-479.

Ogura Y, Bonen DK, Inohara N, Nicolae DL, Chen FF, Ramos R, Britton H, Moran T, Karaliuskas R, Duerr RH, Achkar JP, Brant SR, Bayless TM, Kirschner BS, Hanauer SB, Nunez G, Cho JH 2001. A frameshift mutation in NOD2 associated with susceptibility to Crohn's disease. Nature 411: 603-606.

Oliveira RB, Moraes MO, Oliveira EB, Sarno EN, Nery JA, Sampaio EP 1999. Neutrophils isolated from leprosy patients release TNFalpha and exhibit accelerated apoptosis in vitro. $J$ Leukoc Biol 65: 364-371.

Oliveira RB, Ochoa MT, Sieling PA, Rea TH, Rambukkana A, Sarno EN, Modlin RL 2003. Expression of Toll-like receptor 2 on human Schwann cells: a mechanism of nerve damage in leprosy. Infect Immun 71: 1427-1433.
Omueti KO, Mazur DJ, Thompson KS, Lyle EA, Tapping RI 2007. The polymorphism P315L of human Toll-like receptor 1 impairs innate immune sensing of microbial cell wall components. J Immunol 178: 6387-6394.

Orlova M, Di Pietrantonio T, Schurr E 2011. Genetics of infectious diseases: hidden etiologies and common pathways. Clin Chem Lab Med 49: 1427-1437.

Pannikar V 2009. Enhanced global strategy for further reducing the disease burden due to leprosy: 2011-2015. Lepr Rev 80: 353-354.

Pascual M, Nieto A, Mataran L, Balsa A, Pascual-Salcedo D, Martin J 2000. IL-6 promoter polymorphisms in rheumatoid arthritis. Genes Immun 1: 338-340.

Pedroza LS, Sauma MF, Vasconcelos JM, Takeshita LY, Ribeiro-Rodrigues EM, Sastre D, Barbosa CM, Chies JA, Veit TD, Lima CP, Oliveira LF, Henderson BL, Castro AP, Maia MH, Barbosa FB, Santos SE, Guerreiro JF, Sena L, Santos EJ 2011. Systemic lupus erythematosus: association with KIR and SLC11A1 polymorphisms, ethnic predisposition and influence in clinical manifestations at onset revealed by ancestry genetic markers in an urban Brazilian population. Lupus 20: 265-273.

Pocaterra L, Jain S, Reddy R, Muzaffarullah S, Torres O, Suneetha S, Lockwood DN 2006. Clinical course of erythema nodosum leprosum: an 11-year cohort study in Hyderabad, India. Am J Trop Med Hyg 74: 868-879.

Poikonen K, Lajunen T, Silvennoinen-Kassinen S, Leinonen M, Saikku P 2009. Effects of CD14, TLR2, TLR4, LPB and IL-6 gene polymorphisms on Chlamydia pneumoniae growth in human macrophages in vitro. Scand J Immunol 70: 34-39.

Ramien ML, Wong A, Keystone JS 2011. Severe refractory erythema nodosum leprosum successfully treated with the tumor necrosis factor inhibitor etanercept. Clin Infect Dis 52: e133-135.

Randhawa AK, Shey MS, Keyser A, Peixoto B, Wells RD, de Kock M, Lerumo L, Hughes J, Hussey G, Hawkridge A, Kaplan G, Hanekom WA, Hawn TR 2011. Association of human TLR1 and TLR6 deficiency with altered immune responses to BCG vaccination in South African infants. PLoS Pathog 7: e1002174.

Ranque B, Alcais A, Thuc NV, Woynard S, Thai VH, Huong NT, Ba NN, Khoa PX, Schurr E, Abel L 2005. A recessive major gene controls the mitsuda reaction in a region endemic for leprosy. J Infect Dis 192: 1475-1482.

Ranque B, Nguyen VanÂ T, Vu Hong Â T, Nguyen ThuÂ H, Nguyen NgocÂ B, Pham Xuan Â K, Schurr E, Abel L, Alca ̃̃ SA 2007. Age is an important risk factor for onset and sequelae of reversal reactions in Vietnamese patients with leprosy. Clin Infect Dis 44: 33-40.

Ray A, LaForge KS, Sehgal PB 1990. On the mechanism for efficient repression of the interleukin- 6 promoter by glucocorticoids: enhancer, TATA box and RNA start site (Inr motif) occlusion. Mol Cell Biol 10: 5736-5746.

Rea TH, Sieling PA 1998. Delayed-type hypersensitivity reactions followed by erythema nodosum leprosum. Int J Lepr Other Mycobact Dis 66: 316-327.

Ridley DS, Jopling WH 1966. Classification of leprosy according to immunity. A five-group system. Int J Lepr Other Mycobact Dis 34: $255-273$.

Ridley DS, Radia KB 1981. The histological course of reactions in borderline leprosy and their outcome. Int J Lepr Other Mycobact Dis 49: 383-392.

Roach JC, Glusman G, Rowen L, Kaur A, Purcell MK, Smith KD, Hood LE, Aderem A 2005. The evolution of vertebrate Toll-like receptors. Proc Natl Acad Sci USA 102: 9577-9582. 
Roche M, Convit J, Medina JA, Blomenfeld E 1951. The effects of adrenocorticotropic hormone (ACTH) in lepromatous lepra reaction. Int J Lepr 19: 137-145.

Roche PW, Theuvenet WJ, Britton WJ 1991. Risk factors for type-1 reactions in borderline leprosy patients. Lancet 338: 654-657.

Rodrigues LS, Hacker MA, Illarramendi X, Castelar Pinheiro MF, da Costa Nery JA, Sarno EN, Vidal Pessolani MC 2011. Circulating levels of insulin-like growth factor-I (IGF-I) correlate with disease status in leprosy. BMC Infect Dis 11: 339.

Rook GA, Baker R 1999. Cortisol metabolism, cortisol sensitivity and the pathogenesis of leprosy reactions. Trop Med Int Health 4: 493-498.

Rose P, Waters MF 1991. Reversal reactions in leprosy and their management. Lepr Rev 62: 113-121.

Sampaio EP, Moraes MO, Nery JA, Santos AR, Matos HC, Sarno EN 1998. Pentoxifylline decreases in vivo and in vitro tumour necrosis factor-alpha (TNF-alpha) production in lepromatous leprosy patients with erythema nodosum leprosum (ENL). Clin Exp Immunol 111: 300-308.

San Luciano M, Ozelius L, Lipton RB, Raymond D, Bressman SB, Saunders-Pullman R 2012. Gender differences in the IL-6 $-174 \mathrm{G}>\mathrm{C}$ and ESR2 $1730 \mathrm{G}>\mathrm{A}$ polymorphisms and the risk of Parkinson's disease. Neurosci Lett 506: 312-316.

Sapkota BR, Macdonald M, Berrington WR, Misch EA, Ranjit C, Siddiqui MR, Kaplan G, Hawn TR 2010. Association of TNF, MBL and VDR polymorphisms with leprosy phenotypes. Hum Immunol 71: 992-998.

Sarno EN, Grau GE, Vieira LM, Nery JA 1991. Serum levels of tumour necrosis factor-alpha and interleukin-1 beta during leprosy reactional states. Clin Exp Immunol 84: 103-108.

Saunderson P, Gebre S, Byass P 2000a. ENL reactions in the multibacillary cases of the AMFES cohort in central Ethiopia: incidence and risk factors. Lepr Rev 71: 318-324.

Saunderson P, Gebre S, Byass P 2000b. Reversal reactions in the skin lesions of AMFES patients: incidence and risk factors. Lepr Rev 71: 309-317.

Sawczenko A, Azooz O, Paraszczuk J, Idestrom M, Croft NM, Savage MO, Ballinger AB, Sanderson IR 2005. Intestinal inflammationinduced growth retardation acts through IL-6 in rats and depends on the -174 IL-6 G/C polymorphism in children. Proc Natl Acad Sci USA 102: 13260-13265.

Schaff UY, Shih HH, Lorenz M, Sako D, Kriz R, Milarski K, Bates B, Tchernychev B, Shaw GD, Simon SI 2008. SLIC-1/sorting nexin 20: a novel sorting nexin that directs subcellular distribution of PSGL-1. Eur J Immunol 38: 550-564.

Schuring RP, Hamann L, Faber WR, Pahan D, Richardus JH, Schumann RR, Oskam L 2009. Polymorphism N248S in the human Toll-like receptor 1 gene is related to leprosy and leprosy reactions. J Infect Dis 199: 1816-1819.

Schurr E, Gros P 2009. A common genetic fingerprint in leprosy and Crohn's disease? N Engl J Med 361: 2666-2668.

Scollard DM, Adams LB, Gillis TP, Krahenbuhl JL, Truman RW, Williams DL 2006. The continuing challenges of leprosy. Clin Microbiol Rev 19: 338-381.

Scollard DM, Chaduvula MV, Martinez A, Fowlkes N, Nath I, Stryjewska BM, Kearney MT, Williams DL 2011. Increased CXCL10 levels and gene expression in type 1 leprosy reactions. Clin Vaccine Immunol 18: 947-953.

Scollard DM, Smith T, Bhoopat L, Theetranont C, Rangdaeng S, Morens DM 1994. Epidemiologic characteristics of leprosy reactions. Int J Lepr Other Mycobact Dis 62: 559-567.
Sehgal VN 2005. Lucio's phenomenon/erythema necroticans. Int $J$ Dermatol 44: 602-605.

Shannon EJ, Sandoval FG, Morales MJ 2011. In vitro thalidomide does not interfere with the activation of complement by M. leprae. J Drugs Dermatol 10: 274-278.

Sousa AL, Fava VM, Sampaio LH, Martelli CM, Costa MB, Mira MT, Stefani MM 2012. Genetic and immunological evidence implicates interleukin 6 as a susceptibility gene for leprosy type 2 reaction. J Infect Dis 205: 1417-1424.

Sousa AL, Stefani MM, Pereira GA, Costa MB, Rebello PF, Gomes MK, Narahashi K, Gillis TP, Krahenbuhl JL, Martelli CM 2007. Mycobacterium leprae DNA associated with type 1 reactions in single lesion paucibacillary leprosy treated with single dose rifampin, ofloxacin and minocycline. Am J Trop Med Hyg 77: 829-833.

Sreenivasan P, Misra RS, Wilfred D, Nath I 1998. Lepromatous leprosy patients show $\mathrm{T}$ helper 1-like cytokine profile with differential expression of interleukin-10 during type 1 and 2 reactions. Immunology 95: 529-536.

Stefani MM, Guerra JG, Sousa AL, Costa MB, Oliveira ML, Martelli CT, Scollard DM 2009. Potential plasma markers of type 1 and type 2 leprosy reactions: a preliminary report. BMC Infect Dis 9: 75 .

Stewart LC, Day AS, Pearson J, Barclay ML, Gearry RB, Roberts RL, Bentley RW 2010. SLC11A1 polymorphisms in inflammatory bowel disease and Mycobacterium avium subspecies paratuberculosis status. World J Gastroenterol 16: 5727-5731.

Tada H, Aiba S, Shibata K, Ohteki T, Takada H 2005. Synergistic effect of Nod1 and Nod2 agonists with Toll-like receptor agonists on human dendritic cells to generate interleukin-12 and Thelper type 1 cells. Infect Immun 73: 7967-7976.

Tadesse A, Abebe M, Bizuneh E, Mulugeta W, Aseffa A, Shannon EJ 2006. Effect of thalidomide on the expression of TNF-alpha mRNA and synthesis of TNF-alpha in cells from leprosy patients with reversal reaction. Immunopharmacol Immunotoxicol 28: 431-441.

Takeda Y, Kaneda K, Jimma F, Shiobara N, Hidaka M, Saniabadi AR, Wakabayashi I 2012. Inhibition of CXCL10 release by monomeric C3bi and C4b. Clin Exp Immunol 167: 149-157.

Teixeira MA, Silva NL, Ramos Ade L, Hatagima A, Magalhaes V 2010. NRAMP1 gene polymorphisms in individuals with leprosy reactions attended at two reference centers in Recife, northeastern Brazil. Rev Soc Bras Med Trop 43: 281-286.

Trevilatto PC, Scarel-Caminaga RM, de Brito Jr RB, de Souza AP, Line SR 2003. Polymorphism at position -174 of IL-6 gene is associated with susceptibility to chronic periodontitis in a Caucasian Brazilian population. J Clin Periodontol 30: 438-442.

van Brakel WH, Khawas IB 1996. Nerve function impairment in leprosy: an epidemiological and clinical study - Part 2. Results of steroid treatment. Lepr Rev 67: 104-118.

van Brakel WH, Nicholls PG, Das L, Barkataki P, Suneetha SK, Jadhav RS, Maddali P, Lockwood DN, Wilder-Smith E, Desikan KV 2005. The INFIR Cohort Study: investigating prediction, detection and pathogenesis of neuropathy and reactions in leprosy. Methods and baseline results of a cohort of multibacillary leprosy patients in north India. Lepr Rev 76: 14-34.

Vera-Cabrera L, Escalante-Fuentes WG, Gomez-Flores M, OcampoCandiani J, Busso P, Singh P, Cole ST 2011. Case of diffuse lepromatous leprosy associated with Mycobacterium lepromatosis. J Clin Microbiol 49: 4366-4368.

Verway M, Behr MA, White JH 2010. Vitamin D, NOD2, autophagy and Crohn's disease. Expert Rev Clin Immunol 6: 505-508.

Vidal S, Gros P, Skamene E 1995. Natural resistance to infection with intracellular parasites: molecular genetics identifies Nramp1 as the Bcg/Ity/Lsh locus. J Leukoc Biol 58: 382-390. 
Walker SL, Lockwood DN 2008. Leprosy type 1 (reversal) reactions and their management. Lepr Rev 79: 372-386.

Walker SL, Roberts CH, Atkinson SE, Khadge S, Macdonald M, Neupane KD, Ranjit C, Sapkota BR, Dhakal S, Hawksworth RA, Mahat K, Ruchal S, Hamal S, Hagge DA, Lockwood DN 2012. The effect of systemic corticosteroid therapy on the expression of Toll-like receptor 2 and Toll-like receptor 4 in the cutaneous lesions of leprosy type 1 reactions. Br J Dermatol 167: 29-35.

Walker SL, Waters MF, Lockwood DN 2007. The role of thalidomide in the management of erythema nodosum leprosum. Lepr Rev 78: 197-215.

Wang TT, Dabbas B, Laperriere D, Bitton AJ, Soualhine H, TaveraMendoza LE, Dionne S, Servant MJ, Bitton A, Seidman EG, Mader S, Behr MA, White JH 2010. Direct and indirect induction by 1,25-dihydroxyvitamin D3 of the NOD2/CARD15-defensin beta2 innate immune pathway defective in Crohn disease. $J$ Biol Chem 285: 2227-2231.

Waters MF 2001. Distinguishing between relapse and late reversal reaction in multidrug (MDT)-treated BT leprosy. Lepr Rev 72: 250-253.

Wemambu SN, Turk JL, Waters MF, Rees RJ 1969. Erythema nodosum leprosum: a clinical manifestation of the arthus phenomenon. Lancet 2: 933-935.

White JH 2008. Vitamin D signaling, infectious diseases and regulation of innate immunity. Infect Immun 76: 3837-3843.

WHO - World Health Organization 2011. Leprosy update 2011. Wkly Epidemiol Rec 86: 389-399.
Wong SH, Gochhait S, Malhotra D, Pettersson FH, Teo YY, Khor CC, Rautanen A, Chapman SJ, Mills TC, Srivastava A, Rudko A, Freidin MB, Puzyrev VP, Ali S, Aggarwal S, Chopra R, Reddy BS, Garg VK, Roy S, Meisner S, Hazra SK, Saha B, Floyd S, Keating BJ, Kim C, Fairfax BP, Knight JC, Hill PC, Adegbola RA, Hakonarson H, Fine PE, Pitchappan RM, Bamezai RN, Hill AV, Vannberg FO 2010. Leprosy and the adaptation of human Toll-like receptor 1. PLoS Pathog 6: e1000979.

Wurfel MM, Gordon AC, Holden TD, Radella F, Strout J, Kajikawa O, Ruzinski JT, Rona G, Black RA, Stratton S, Jarvik GP, Hajjar AM, Nickerson DA, Rieder M, Sevransky J, Maloney JP, Moss M, Martin G, Shanholtz C, Garcia JG, Gao L, Brower R, Barnes KC, Walley KR, Russell JA, Martin TR 2008. Toll-like receptor 1 polymorphisms affect innate immune responses and outcomes in sepsis. Am J Respir Crit Care Med 178: 710-720.

Yang Han X, Clement Sizer K, Tan HH 2012. Identification of the leprosy agent Mycobacterium lepromatosis in Singapore. J Drugs Dermatol 11: 168-172.

Zhang FR, Huang W, Chen SM, Sun LD, Liu H, Li Y, Cui Y, Yan XX, Yang HT, Yang RD, Chu TS, Zhang C, Zhang L, Han JW, Yu GQ, Quan C, Yu YX, Zhang Z, Shi BQ, Zhang LH, Cheng H, Wang CY, Lin Y, Zheng HF, Fu XA, Zuo XB, Wang Q, Long H, Sun YP, Cheng YL, Tian HQ, Zhou FS, Liu HX, Lu WS, He SM, Du WL, Shen M, Jin QY, Wang Y, Low HQ, Erwin T, Yang NH, Li JY, Zhao X, Jiao YL, Mao LG, Yin G, Jiang ZX, Wang XD, Yu JP, Hu ZH, Gong CH, Liu YQ, Liu RY, Wang DM, Wei D, Liu JX, Cao WK, Cao HZ, Li YP, Yan WG, Wei SY, Wang KJ, Hibberd ML, Yang S, Zhang XJ, Liu JJ 2009. Genomewide association study of leprosy. $N$ Engl J Med 361: 2609-2618. 